\title{
Eight organizational enablers of digital service-sales ambidexterity in industrial firms
}

\author{
Moritz Classen and Thomas Friedli \\ Institute of Technology Management, University of St. Gallen, St. Gallen, Switzerland
}

\begin{abstract} industrial firms expanding their digital service portfolios. micro and meso levels. and to explore new digital growth paths. operationalizing eight organizational enablers.

Paper type Research paper

The sales rep needs to achieve a certain sales quota. It's easier for him to achieve it if he sells maintenance and repair at a large scale and nothing 'digital' at all. I don't want to insinuate anything, but [...] the effort and benefit of these digital products do not match for the sales rep. (Sales \& Process Manager - Digital Products)
\end{abstract}

Purpose - The purpose of this study is to explore organizational enablers of frontline employees' (FLEs) service-sales ambidexterity (SSA) in

Design/methodology/approach - The authors conducted a qualitative study of five industrial firms pursuing digital service growth and, for this purpose, collected and analyzed interview data obtained from 50 service and sales managers and FLEs across three continents.

Findings - The authors identify and explain eight organizational enablers of digital service-sales ambidexterity (DSSA), operating at the macro,

Practical implications - Service and sales managers should use the identified organizational enablers to exploit the established service business

Originality/value - The study expands the prior understanding of SSA by advancing the concept of DSSA, unpacking its multilevel dynamics and

Keywords Manufacturing industry, Organizational change, Service marketing, Industrial marketing, Salesforce, Industrial selling, Service-sales ambidexterity, Digital services, Digital servitization, Industrial services, Smart services, B2B sales, Service sales, Servitization, Multilevel research

\section{Introduction}

Industrial firms must balance conflicting aims to remain competitive. Facing margin erosion on equipment sales, firms have implemented service transition strategies since the $1990 \mathrm{~s}$ (Wise and Baumgartner, 1999). More recently, rapidly evolving information technology (IT) has unlocked new opportunities to expand through digital services. Manufacturers pursue ambidexterity by managing trade-offs (Gibson and Birkinshaw, 2004) between exploiting the established physical service[1] business and exploring digital service opportunities. In parallel, frontline employees (FLEs) are now expected to perform service and sales tasks, thereby displaying service-sales ambidexterity (SSA; Rapp et al., 2017; Ruyter et al., 2020). In short, both organizations and individuals should become ambidextrous.

Against this backdrop, three knowledge gaps are discerned. First, the service transition literature has largely ignored the complementarity of service and sales, instead highlighting the opposing objectives and cultures that separate service from sales (Burton et al., 2016). SSA literature suggests, by contrast, that the areas can reinforce each other (Yu et al., 2013). Combining

The current issue and full text archive of this journal is available on Emerald Insight at: https://www.emerald.com/insight/0885-8624.htm

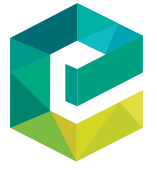

Journal of Business \& Industrial Marketing

(C) Emerald Publishing Limited [ISSN 0885-8624]

[DOI 10.1108/JBIM-02-2021-0080] these two bodies of literature is rewarding because it can guide industrial firms' managers who are struggling to convert the frontline into service sellers (Ulaga and Loveland, 2014).

Second, SSA research has not fully considered service digitalization. None of the SSA studies reviewed by Mullins et al. (2020) explicitly discuss digital services. Despite calls to study the implications of digitalization on sales (Singh et al., 2019), recent literature primarily explores the digital transformation of sales operations (Giovannetti et al., 2020; Guenzi and Habel, 2020) rather than service portfolios. This is unfortunate. We expect digital services to shape an everincreasing number of frontline activities and to further exacerbate role ambiguity (Gabler et al., 2017). Managers need insight into what we call digital SSA (DSSA) to understand which behaviors support digital service growth strategies.

Third, it is necessary to shed light on the organizational enablers of SSA. There is mounting evidence that firms struggle to create boundary conditions conducive to SSA (Jasmand et al., 2012). More broadly, organizational mechanisms facilitating SSA are underresearched (Hughes and Ogilvie, 2020; Ruyter et al., 2020; Yu et al., 2013; Yu et al., 2015). This void deserves more attention and closer inspection because leaders should know which levers to pull to spur SSA.

To address these gaps, we examine the following research question: What are the organizational enablers of DSSA? To answer

This article is based on the first author's dissertation, which was chaired by the second author. This work was supported by the Swiss Innovation Agency Innosuisse under grant 34121.1 IP-SBM.

Received 4 February 2021

Revised 23 June 2021

11 September 2021

23 October 2021

Accepted 24 October 2021 
this question, we conduct a qualitative study of five industrial firms expanding through digital services. Our contributions are threefold. First, we theorize the DSSA concept. In doing so, we bridge the servitization and SSA literature and explain the mechanisms through which the service-sales interface can turbocharge - or stall - the digital service growth engine. Second, we build on and extend multilevel SSA research by operationalizing organization-level and individual-level DSSA. Our results show that DSSA is a dynamic capability formed by individual DSSA behavior. This finding bolsters the frontline's crucial role in generating organizational capabilities. Third, we shed light on eight organizational enablers of DSSA. By revealing a certain equifinality of structural and contextual approaches, we enhance prior understandings of ambidexterity. This observation suggests that leaders can follow different paths to reach exploration and exploitation goals. Table 1 summarizes the research gaps and our contributions. In what follows, we discuss the theory, present our research method and findings, discuss theoretical and managerial implications and conclude with directions for future research.

\section{Theoretical background}

\subsection{Service transition in industrial firms}

\subsubsection{Servitization}

Many industrial firms expand their business-to-business (B2B) service portfolios to counter eroding margins on equipment sales. This strategic shift, termed servitization (Vandermerwe and Rada, 1988), assumes that services can create a competitive advantage based on valuable, rare, inimitable and organized resources (Eloranta and Turunen, 2015; Kozlenkova et al., 2014; Opresnik and Taisch, 2015). Conceptually, firms servitize to generate high-margin, steady revenues (Oliva and Kallenberg, 2003; Wise and Baumgartner, 1999). Empirically, servitization is associated with higher corporate valuation (Fang et al., 2008), revenue (Böhm et al., 2017) and revenue growth (Nezami et al., 2018). However, its overall profitability impact is less evident (Eggert et al., 2014) and is moderated by the firm's service sales capability (Worm et al., 2017).

This capability hinges on service and sales FLEs' knowledge, skills and abilities (KSAs). Many service FLEs have historically provided services free of charge, thereby undermining value capture opportunities (Gebauer and Friedli, 2005). Similarly, manufacturers struggle to turn their goods-centric sales force into service sellers (Ulaga and Reinartz, 2011). First, the attributes of salespeople conducive to goods and service sales differ (Burton et al., 2017). While goods-centric salespeople typically focus on deal closing (hunters), service salespeople emphasize customer retention (farmers) (DeCarlo and Lam, 2016; Ulaga and Loveland, 2014). Second, the selling of services requires specialized KSAs. They include the ability to connect with higher-level decision-makers in the customer organization, to identify customer-specific value drivers and to communicate the value of services (Huikkola and Kohtamäki, 2017; Kindström and Kowalkowski, 2014). Third, compensation plans tend to incentivize equipment sales (Kindström and Kowalkowski, 2014). Because equipment typically generates higher one-off revenue than services and most sales compensation plans reward revenue (Churchill et al., 1985; Turunen and Neely, 2012), many salespeople seem less enthusiastic about selling services (Reinartz and Ulaga, 2008).

Nonetheless, literature is sparse on organization-level mechanisms that alleviate tensions at the service-sales interface. These tensions arise from conflicting objectives, cultures and modes of operation (Burton et al., 2016; Lütjen et al., 2017; Paiola et al., 2013; Turunen and Neely, 2012). Servitization research has suggested organizational levers to overcome these conflicts, including service-specific sales forces, roles,

Table 1 Research gaps and contributions

\begin{tabular}{|c|c|c|c|}
\hline & & Prior research & Current research \\
\hline \multirow[t]{2}{*}{ Servitization research } & Service-sales interface & $\begin{array}{l}\text { Service and sales are antagonistic: separate } \\
\text { units Paiola et al., } 2013 \text { with opposing } \\
\text { objectives, cultures (Burton et al., 2016) and } \\
\text { degrees of formalization (Turunen and Neely, } \\
\text { 2012) }\end{array}$ & $\begin{array}{l}\text { Service and sales are synergistic: } \\
\text { complementary KSAs, roles, organizational } \\
\text { units and control systems }\end{array}$ \\
\hline & Unit of analysis & $\begin{array}{l}\text { Individuals: service technicians (Gebauer and } \\
\text { Friedli, 2005) and salespeople (Reinartz and } \\
\text { Ulaga, 2008; Ulaga and Loveland, 2014) }\end{array}$ & $\begin{array}{l}\text { Individuals nested in the service and sales } \\
\text { departments }\end{array}$ \\
\hline \multirow[t]{4}{*}{ SSA research } & Scope of ambidexterity & $\begin{array}{l}\text { Simultaneous pursuit of service and sales goals } \\
\text { (Yu et al., 2013) }\end{array}$ & $\begin{array}{l}\text { Simultaneous pursuit of service and sales } \\
\text { goals for physical and digital services }\end{array}$ \\
\hline & Focal industry & $\begin{array}{l}\text { Service industries (e.g. beauty salons, Yu et al., } \\
\text { 2018; call centers, Jasmand et al., 2012; } \\
\text { financial services, Hughes and Ogilvie, 2020; } \\
\text { hospitality, Ogilvie et al., 2017) or industry mix } \\
\text { (Mullins et al., 2020; Panagopoulos et al., 2020; } \\
\text { Patterson et al., 2014). }\end{array}$ & Industrial equipment manufacturers only \\
\hline & Level of analysis & $\begin{array}{l}\text { Primarily single level: organizational level (Yu } \\
\text { et al., 2013) or individual level (Gabler et al., } \\
\text { 2017; Jasmand et al., 2012; Yu et al., 2015) }\end{array}$ & Multilevel: macro, micro and meso levels \\
\hline & Organizational enablers & Virtually not examined & $\begin{array}{l}\text { Identifies and explains eight organizational } \\
\text { enablers }\end{array}$ \\
\hline
\end{tabular}


processes, units and incentives (Burton et al., 2016; Gebauer et al., 2005; Gebauer and Friedli, 2005; Kindström et al., 2015; Rabetino et al., 2017). However, our understanding of the levers' detailed design remains limited (Raddats et al., 2019).

\subsubsection{Digital servitization}

Digital servitization is the "transition toward smart productservice-software systems that enable value creation and capture through monitoring, control, optimization and autonomous function" (Kohtamäki et al., 2019, p. 383). It has propelled the creation of new value propositions, business models and revenue streams that complement physical assets with digital services (Coreynen et al., 2017; Opresnik and Taisch, 2015; Suppatvech et al., 2019; Vendrell-Herrero et al., 2017). For example, Bühler, a manufacturer of food processing equipment, sells a cloud-based service to monitor, visualize and analyze production data, for annual subscription fees up to EUR 100,000 (Gebauer et al., 2020).

Digital servitization accelerates change in the sales function. The sales force must clearly understand what value digital services create to explain and sell them (Hasselblatt et al., 2018). Many industrial sales forces lack this understanding and, as a result, miss their sales targets (Klein et al., 2018; Töytäri et al., 2018). To overcome these challenges, sales force transformation is imperative (Paiola and Gebauer, 2020). Importantly, more research is required to understand how sales organizations should adapt roles, structures and control systems to improve digital services selling (Singh et al., 2019).

\subsection{Service-sales ambidexterity}

\subsubsection{Service-sales ambidexterity as dynamic capability}

We study organizational capabilities from a multilevel perspective. That is, we analyze several capability levels (Salvato and Rerup, 2011) to interpret "much of the nested complexity of real organizational life" (Klein and Kozlowski, 2000, p. 211). Higher-level dynamic capabilities allow firms to "purposefully create, extend, or modify [their] resource base" (Helfat et al., 2007, p. 4), including their operational capabilities (Collis, 1994; Teece et al., 1997; Winter, 2003). Operational capabilities - notably service selling and fulfillment (Morgan, 2012) - are underpinned by lower-level microfoundations, such as routines, organizational structures and individual KSAs (Felin et al., 2012; Teece, 2007).

Organizational ambidexterity is a specific dynamic capability (O'Reilly and Tushman, 2008). Ambidexterity refers to an organization's ability to both explore and exploit (March, 1991; O'Reilly and Tushman, 2013). Gibson and Birkinshaw (2004) distinguish between structural ambidexterity, which uses separate organizational units to achieve these conflicting goals and contextual ambidexterity, which denotes the capacity to explore and exploit within an organizational unit.

SSA applies ambidexterity to the service-sales interface and has, specifically, been analyzed at the organizational and individual levels (Mullins et al., 2020; Panagopoulos et al., 2020; Ruyter et al., 2020). Organization-level SSA is a single organizational unit's "simultaneous pursuit of service and sales goals" (Yu et al., 2013, p. 53). Individual-level SSA is an FLE's "engagement in both customer service provision and cross-/upselling during service encounters" (Jasmand et al., 2012, p. 22). Given the reciprocal effects of organization-level and individual-level capabilities, we agree with Rapp et al. (2017) and conceptualize SSA as dynamic capability formed by individual-level behavior nested in the sales-service interface.

A multilevel perspective is essential to study drivers of SSA behavior (Hughes and Ogilvie, 2020; Rapp et al., 2017). Conceptually, SSA can emerge from organizational forces or employee self-regulation (Yu et al., 2013). Companies have historically used structural mechanisms like the separation of service and sales functions to overcome the goal conflicts inherent in SSA, and to achieve structural ambidexterity (Hochstein et al., 2021; Ruyter et al., 2020). Nevertheless, expectations have increased and service FLEs are required to achieve sales targets and salespeople to provide services (Ruyter et al., 2020). Given these goal conflicts, and to attain contextual ambidexterity, FLEs must wittingly choose between service and sales activities and adapt their behavior accordingly (Jasmand et al., 2012). However, self-regulation depends on individual motivation and KSAs, which differ across FLEs (Jasmand et al., 2012; Sok et al., 2016; Yu et al., 2015).

Therefore, companies must create an organizational context conducive to SSA behavior (Agnihotri et al., 2017). To do so, managers can adapt recruitment and training routines, resource deployment, control systems and sales support tools (DeCarlo and Lam, 2016; Hughes and Ogilvie, 2020). While empirical studies on individual-level and organization-level antecedents to SSA have emerged (Mullins et al., 2020), more multilevel research is required to explore the organizational enablers of SSA (DeCarlo and Lam, 2016; Hughes and Ogilvie, 2020; Lam et al., 2019; Rapp et al., 2017; Shiue et al., 2021).

\subsubsection{Digital service-sales ambidexterity}

Discussions on SSA and B2B service digitalization have evolved separately. Recent literature acknowledges the role of digital technologies in facilitating selling (Giovannetti et al., 2020; Guenzi and Habel, 2020; Singh et al., 2019) and, ultimately, SSA (Ruyter et al., 2020). However, to our knowledge, no research article has studied how the digitalization of service portfolios affects SSA.

This is surprising, as digital servitization might worsen the exploitation/exploration dilemma at the service-sales interface. As digital servitization unfolds, manufacturers add digital services to their portfolio of physical goods and services. Thereby, they exploit existing portfolio elements while exploring new digital opportunities (Coreynen et al., 2020; Ritter and Pedersen, 2019). Both options could be incompatible because digital services (e.g. remote monitoring) might cannibalize revenues from physical services (e.g. field inspection) (Gebauer et al., 2020). Therefore, ambidextrous FLEs must not only perform service and sales roles (Mullins et al., 2020) but also balance physical and digital services.

Adhering to our multilevel perspective, we propose two forms of DSSA. At the organizational level, we conceptualize $D S S A$ as a dynamic capability that reflects a firm's ability to achieve service and sales outcomes through physical and digital services. At the individual level, we define DSSA behavior as FLEs' engagement in service and sales activities for physical and digital services. In doing so, we conceptualize DSSA behavior as a microfoundation of the DSSA capability. Figure 1 shows that our DSSA definition adds a digital layer to prior 
Figure 1 DSSA

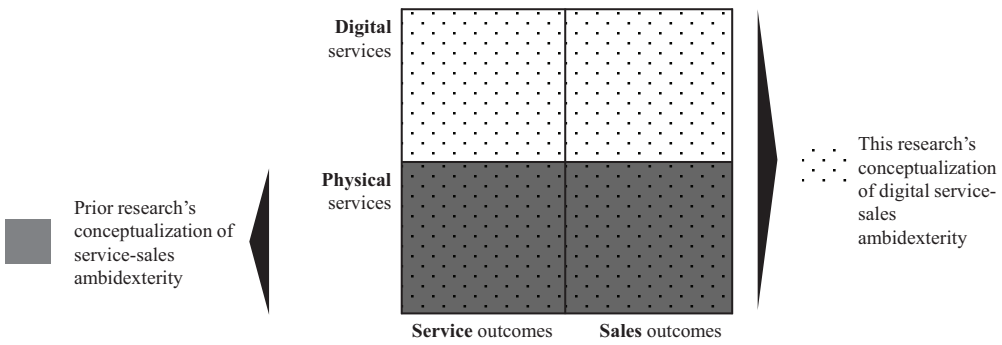

SSA conceptualizations. It is the drivers of individual DSSA behavior - which underpin organizational DSSA - that we investigate in this study.

\section{Methodology}

We conducted an inductive, exploratory study of five industrial firms' efforts to stimulate DSSA. In each firm, we investigated the behavior of individuals nested in the service and sales departments.

\subsection{Data collection}

Our sample included five globally operating industrial firms headquartered in Europe (Table 2). We selected these firms because they pursued digital servitization, emphasized DSSA and granted us access to key informants. The number of cases examined (5) is within the boundaries, suggested by qualitative methodologists (Eisenhardt, 1989; Yin, 2018), to develop a theory that balances parsimony and depth, and suffices for our "maximum variation" sampling strategy (Patton, 2002). The firms varied considerably in terms of:

- industry;

- maturity of digital service portfolio (e.g. 10-year history of remote monitoring vs first pilots in the pipeline); and
- primary ways of selling services (e.g. dedicated service salespeople vs service technicians).

Contrasting patterns between cases emerged from this heterogeneity, allowing us to build theory (Eisenhardt, 1989) around DSSA.

The data was obtained by means of 50 semi-structured interviews. The informants held managerial and frontline positions in the firms' European, Asian and American service or sales organizations. This variety of geographies, functional areas and hierarchical levels not only enabled us to understand managerial and frontline DSSA behavior but also to learn from "deviants" (Miles et al., 2014) - for instance, service technicians or sales executives who showed no interest in selling services. The number of informants per case reflected the heterogeneous maturity of the digital service portfolios: Venus had only recently formed a cross-functional team to pilot digital services globally[2], while Neptune's service sales force had been selling digital services for years. The face-to-face and video interviews lasted between 52 and $117 \mathrm{~min}$ ( $81 \mathrm{~min}$ on average). All interviews, except two, were recorded and transcribed.

\subsection{Data analysis}

We analyzed our data in three steps. First, we used open coding (Corbin and Strauss, 2008) in ATLAS.ti to capture

Table 2 Firms and informants

\begin{tabular}{|c|c|c|c|c|c|c|}
\hline $\begin{array}{l}\text { Firm } \\
\text { (Pseudonym) }\end{array}$ & Core products & Core services & $\begin{array}{l}\text { Revenue } \\
\text { [EUR m] }\end{array}$ & Employees & $\begin{array}{c}\text { No. of } \\
\text { informants }\end{array}$ & Informant roles \\
\hline Jupiter & $\begin{array}{l}\text { Industrial automation } \\
\text { components }\end{array}$ & $\begin{array}{l}\text { Spare parts, maintenance, } \\
\text { predictive maintenance, } \\
\text { cyber-security solutions }\end{array}$ & 737 & 2,243 & 10 & $\begin{array}{l}\text { Head of Sales and Marketing, Head } \\
\text { of Service, Industry Services } \\
\text { Consultant }\end{array}$ \\
\hline Mars & $\begin{array}{l}\text { Rolling stock, rail } \\
\text { automation and } \\
\text { electrification }\end{array}$ & $\begin{array}{l}\text { Spare parts, maintenance, } \\
\text { full-service contracts, } \\
\text { predictive maintenance }\end{array}$ & 284 & 949 & 7 & $\begin{array}{l}\text { Business Unit Head, Director } \\
\text { Services, Head of Sales, Senior } \\
\text { Account Manager, Sales Manager }\end{array}$ \\
\hline Neptune & Elevators, escalators & $\begin{array}{l}\text { Spare parts, maintenance, } \\
\text { full-service contracts, remote } \\
\text { monitoring, digital } \\
\text { advertising services }\end{array}$ & 10,340 & 66,306 & 13 & $\begin{array}{l}\text { Global Sales Manager, Commercial } \\
\text { Deployment Manager, Sales \& } \\
\text { Process Manager, Service Leader, } \\
\text { Service Sales Manager, Key } \\
\text { Account Manager, Region } \\
\text { Manager }\end{array}$ \\
\hline Pluto & Textile machinery & $\begin{array}{l}\text { Spare parts, maintenance, } \\
\text { remote monitoring }\end{array}$ & 1,200 & 5,500 & 17 & $\begin{array}{l}\text { Head of Customer Service, Division } \\
\text { Manager, Area Sales Manager, } \\
\text { Service Manager }\end{array}$ \\
\hline Venus & $\begin{array}{l}\text { Laser systems, machine } \\
\text { tools }\end{array}$ & $\begin{array}{l}\text { Spare parts, maintenance, } \\
\text { remote monitoring }\end{array}$ & 3,231 & 14,325 & 3 & $\begin{array}{l}\text { Business Developer Smart Services, } \\
\text { Sales Manager, Service Manager }\end{array}$ \\
\hline
\end{tabular}


informants' perspectives on DSSA. Drawing on the raw interview data, we inductively generated first-order codes based on informants' conception of "what is going on" (van Maanen, 1979, p. 540). By reviewing the data multiple times, we constantly refined, expanded and merged the first-order codes. Saturation (Glaser and Strauss, 1967) occurred when revisiting the data failed to generate any new insights. Next, we compared and established relationships between first-order codes (Gioia et al., 2013), resulting in 14 initial second-order themes.

Second, we discussed the emerging results with practitioners. To ensure the internal consistency of our findings, we successively presented intermediate results to each of the firms, except for one firm. Based on the feedback, we refined the second-order themes between each presentation. Following these iterations, we presented our results - in an online seminar - to more than 75 practitioners representing a broad range of industries. The seminar feedback enhances confidence in the transferability (Miles et al., 2014) of our findings.

Third, we entered the theoretical realm by comparing our second-order themes with those in the literature. Constant comparison and theoretical abstraction (Strauss, 1987) reduced the number of second-order themes to eight. In an ongoing dialogue between our data and extant literature (Hughes and Ogilvie, 2020), we assembled the second-order themes into aggregate dimensions (Gioia et al., 2013). Although our initial unit of analysis was the individual FLE, it soon became apparent from the data that DSSA enablers span multiple levels (Nag and Gioia, 2012; Rapp et al., 2017). Our data structure (Figure 2) reveals that DSSA enablers operate at the macro, micro and meso levels.

\section{Findings}

We identified eight organizational enablers of DSSA (Figure 3). We use pseudonyms for the firms and alphanumeric codes for the informants in the description of our findings.

\subsection{Macro-level enablers}

\subsubsection{Refining objectives}

Tradeoffs between the exploitation of physical services and the exploration of digital service opportunities appeared early during the strategy definition. All firms had defined digitalization strategies to increase the share of digital elements in their service portfolios, fulfillment and revenue. Executives had to make strategic choices between the pursuit of stable, high-margin revenue from physical services or, instead, waging on digital growth:

[Digital services] are the business of tomorrow. The spare parts business is eroding, and field services are less in demand and done by others. The digital business is our investment for tomorrow. At the moment, pure digital offerings just make up [...] a small, an extremely small share of revenue.. But growth rates are much higher. They're somewhere around double-digit, whereas those of traditional services are between one and five percent at most. (J10)

Strategies underwent major shifts along the way. Initially, the firms set aggressive revenue objectives for their digital business. However, market feedback on initial digital service offerings indicated that most revenue objectives were overambitious. Consequently, executives gradually shifted from a narrow focus on digital service revenue to a broader set of objectives, including cross-selling. The main commercial objective of digital services became the increase of the sales of spare parts (Pluto) or maintenance contracts (Neptune). Jupiter pivoted radically from considering digital services as a "door opener" for equipment sales to the exact opposite:

We initially thought that digitalization would be an enabler for everything else that we carry around in our vendor's tray. In the meantime, it has become a sideline to our basic business. We sell controllers and if you want a connection to the ERP [enterprise resource planning] or the cloud, we have that as well. I think the initial euphoria that this will be a free lunch has died down a bit. (J07)

Sales strategies were operationalized at the FLE level in three steps. First, objectives were broken down to service types. Pluto distinguished between maintenance and spare parts sales targets because of the relative difficulty of selling maintenance in many of its core Middle Eastern and East Asian markets. To lay the foundation for digital service growth, Neptune defined the quota of connected assets on total equipment sales that subsidiaries had to fulfill. This quota was successively deconstructed by regions and sales territories.

Second, sales strategies were localized. The firms' market share and brand strength varied significantly between countries. So did the customers' willingness to pay for services. As an informant noted: "Our situation is different from China or from India. So, the Japanese customer is [gentler]" (P15). Revenue targets were adjusted accordingly to gain frontline acceptance.

Third, sales initiatives were prioritized. Services were mainly sold to existing accounts. Therefore, salespeople had to examine their accounts' full revenue potential across offerings before starting isolated sales initiatives:

There are [sales]people who don't care about the damage in other divisions: 'Go for it! The main thing is that I've sold my three bolts, regardless of whether the other guy can sell the whole car in the end or not.' Services have a maximum revenue share of five to ten percent. Someone can come in with a service offering and cause trouble with a customer because of 10,000 francs and ruin my million-francs business. (M04)

\subsubsection{Reallocating resources}

The exploitation/exploration dilemma was reinforced by the unequal resource demands imposed by selling physical and digital services. Neptune is a case in point. Because many countries mandated elevator maintenance by law, bundling contracts with new equipment sales effortlessly generated revenue. Selling digital services, by contrast, consumed substantial resources to verify and explain technical details. FLEs faced major goal conflicts:

[This digital service] requires an on-site meeting to discuss whether the customer can envision it. Then a second meeting in which a colleague joins to do the technical assessment. Now we will schedule another meeting to discuss the offering with the customer. And I mean [...] usually it's like, when I offer a classic repair for EUR 2,000, I send it through to the customer, and he orders. (N06)

Resource reallocation facilitated DSSA. Neptune started experimenting with hybrid sales structures to overcome resource bottlenecks in frontline sales. Tele-sales were deployed to find leads for digital services, thereby freeing FLE capacity. Field sales took over later:

Australia is one example. They are very focused. They have great people who know what they're doing. [...] They sell non-stop. They have a plan in which they go out in a structured, very simple way. They bypass today's service sales team with a call center, saying that a well-briefed call center can easily generate leads for [digital services]. Only then, when it's prepared anyway, when the first round of explanation is done, typical sales force comes in. What are the advantages of that? They can focus on selling, in the 
Figure 2 Data structure

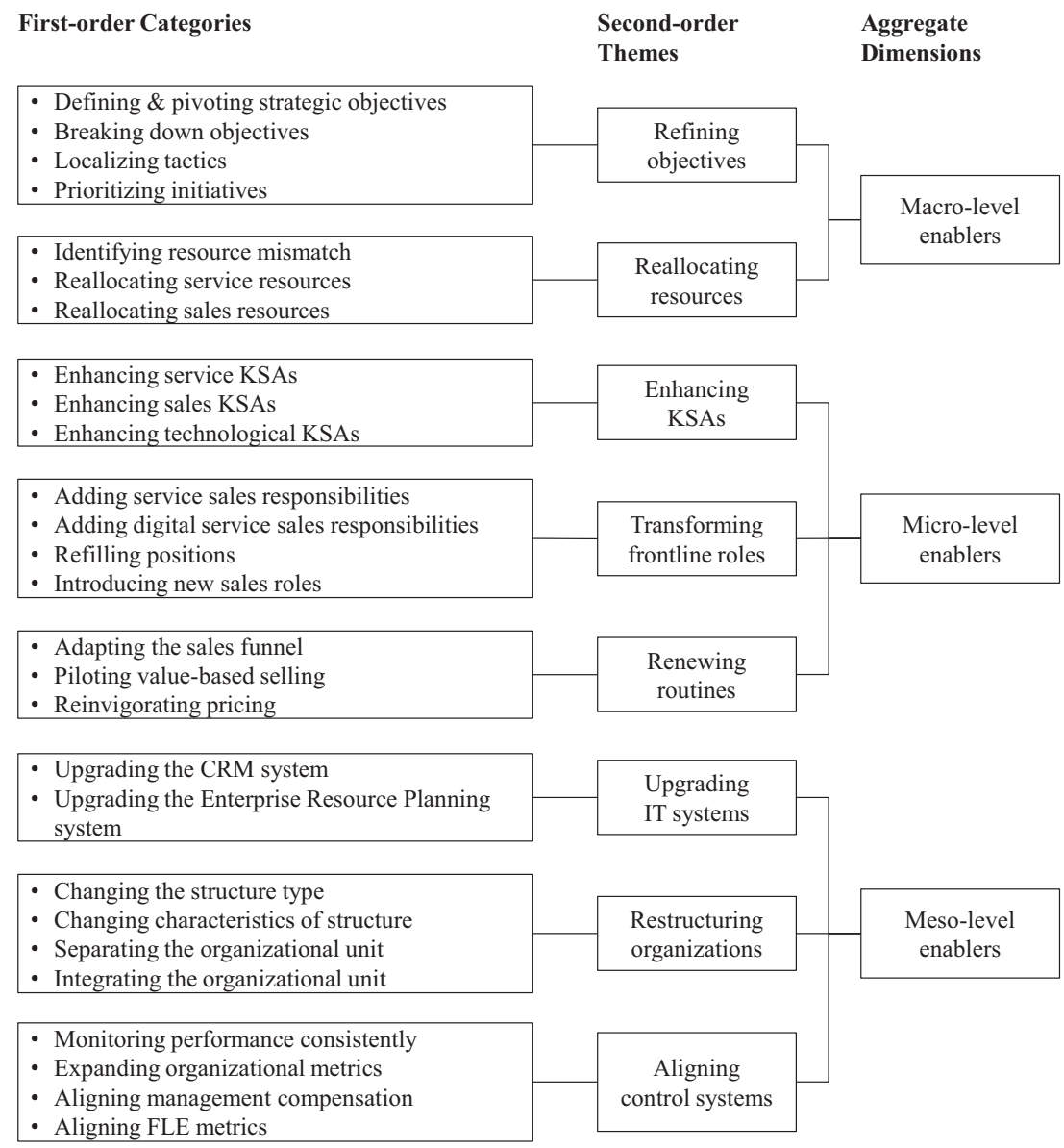

Figure 3 Eight organizational enablers of DSSA

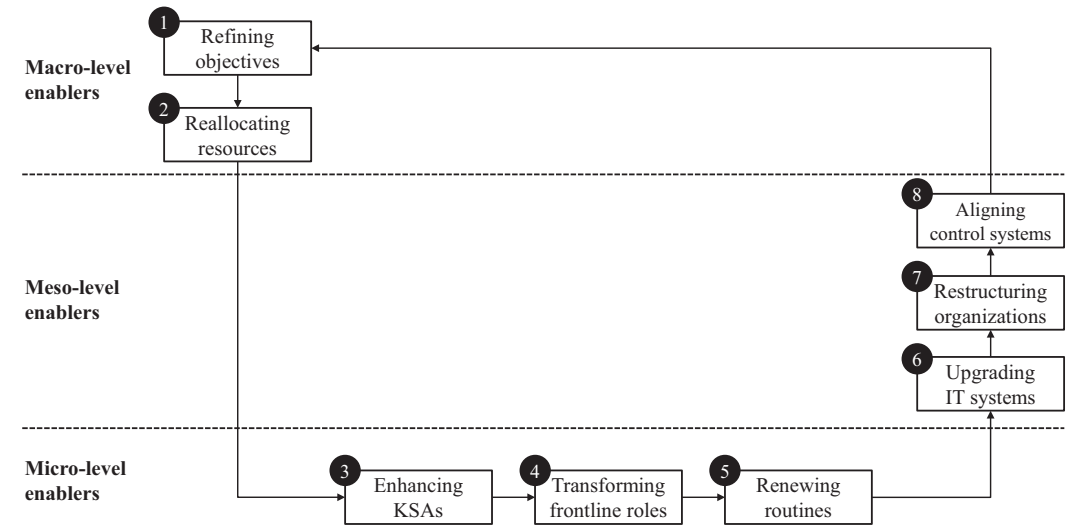

sense of concluding the contract, and no longer have to deal with explaining the product. They can just clear the formalities. It works quite well. (N07)

\subsection{Micro-level enablers}

\subsubsection{Enhancing knowledge, skills and abilities}

To achieve service and sales objectives, FLEs should improve customer service, selling and digital technology KSAs. Foremost, excellent customer service was foundational for later sales. This principle, while intuitively appealing, was applied inconsistently across the frontline. Service quality was subject to individual agency:

I love my job - even [though] I work for this company for 27 years, [I] am still very active. This is my hobby. I want to build up the relationship with the customers. Then I'm happy. This is my hobby; [it is] not about the money. OK, you give me a fixed amount of money, but I'm also reacting this way. This is my character. But I would like our company to arrange some training to motivate the other people. We must give more training to 
salespeople and service technicians to motivate [them and change] their attitude. (P06)

Moreover, both service and sales FLEs had sufficient room to improve service selling KSAs. Service FLEs, having frequent interactions and close relationships with customers, were in a prime position to sell services. Their intimate knowledge of customer needs allowed service FLEs to recognize natural cross-selling and up-selling opportunities. However, service FLEs seldom fully exploited their respective positions' potential. Many were unwilling or underqualified to accept sales responsibilities:

When customers start saying 'That's too expensive for me' - that's not my world. Sure, I can argue and justify that. But that's not what I like to do. Other people can do that better than me. That's why I'm not a salesperson. (J09)

I have a sales[person] who was a technician for us for 20 years and has now joined the sales department. He knows the technical side of things very well. But the sales strategy? That's all new to him. (P03)

Many goods-centric salespeople still had to become service sellers. This required a fundamental, albeit often missing understanding of services as a creator of value for customers and, consequently, for providers. In the absence of this consensus, "sales mostly just try to sell the machine [and] never care about the service" (P10). Additional KSA gaps appeared around the following aspects:

- selling services proactively;

- recognizing performance improvement opportunities in customer operations;

- identifying and creating the need for digital services;

- feeding these needs back into the vendor organization; and

- understanding new service-related revenue models.

Finally, FLEs had to enhance their understanding of the digital technology embedded in new services. Despite extensive knowledge about equipment and their maintenance, longtenured FLEs struggled to grasp how digital services worked:

Mechanics and technicians think rather logically and know elevators. But all things digital that disappear somewhere and then somehow get computed at the headquarters [...] are somewhat intangible. (N03)

Two crucial KSA-enhancing mechanisms emerged from the data. Regular training tailored to different frontline roles served as the primary enabler. Workshops that provided FLEs with firsthand practice were pivotal. Most workshops on digital services featured a Digital Technology 101. However, the workshop exercises that clarified the customer value of digital features, such as role plays to recognize use-cases in customer interactions, were more important. Intuitive sales brochures the second enabler - were essential if the training knowledge were to remain. Unfortunately, most brochures emphasized technical details over tangible customer benefits, thereby not gaining frontline acceptance. To overcome these challenges, a Neptune subsidiary installed showrooms displaying digital services at its headquarters.

\subsubsection{Transforming frontline roles}

Frontline roles underwent three transformational changes as service portfolios evolved. First, existing frontline roles were expanded with service sales responsibilities. Pluto's sales force's main task was to sell new equipment. Additional service offerings, such as spare parts packages, were addressed only if the situation allowed it. However, role expansions could result in goal conflicts. Because equipment deals with price-sensitive customers could collapse if services were added, some of Neptune's salespeople deliberately refrained from promoting services:

Every salesperson avoids talking about [maintenance contracts], because we are upper league, pricewise. Some small shops charge a half to a fifth of our price. And extrapolating that to an elevator's lifecycle of 20 years. . . you have to see how you can sell that. Back when I was selling modernizations, if I could avoid talking about maintenance, it didn't come up. And I think that's still commonplace, especially with new installations. (N05)

Second, dedicated service sales roles were introduced. At Jupiter and Neptune, service salespeople were assigned to sales territories where they worked alongside equipment salespeople. Both sales forces were then tasked with the selling of digital services. This seemed like a natural choice, given their geographic coverage. However, some salespeople, especially those with considerable experience, struggled with the digital side of SSA:

Some salespeople simply cannot be digitalized. They have sold switches for 20,30 years. Now [the salesperson] suddenly has to sell something that he can't even touch; that annoys him anyway because the computer annoys him all day long. Now he is supposed to sell it. This going to be relatively difficult. It's the mindset on which we need to work. And it is also the education and quality of these salespeople, of which not all are able or willing to become digital salespeople. (J07)

Natural employee fluctuation facilitated DSSA. To accelerate frontline transformation, vacancies were gradually refilled with new recruits showing a greater inclination for all things digital:

The conservative salespeople [[...] are eventually] going to die [...] They will retire, and new, younger salespeople will take their place. Unless they're hired by the age of 59, they are the ones who will bring in [digital services selling skills]. The new generation of salespeople - who are in their late 20 s and early $30 \mathrm{~s}$ - have a different relationship to [digital services]. They don't see every cloud solution primarily as a gateway for hackers, spies, and such things. Instead, they have already grown up in this environment. So, they have fewer reservations. The others will not be able to be straightened out; they will continue to sell their contactors and motor protection switches. (J07)

Third, new frontline, intermediary and backend roles were introduced for digital service sales. New frontline roles included digital service sales representatives and business developers. This role configuration merged depth - with a single, dedicated role focusing on digital expertise and breadth - with traditional roles covering sales territories. Typically, area sales managers identified new leads and handed them over to digital service sales representatives, who closed the sale.

Digital service champions played a pivotal intermediary role. Champions worked closely with corporate headquarters to boost subsidiaries' adoption of digital services. To do so, champions trained local sales forces, accompanied colleagues who visited customers to pitch digital services and fed market information back to the organization.

New backend roles updated sales processes and systems for digital services. Neptune introduced a process manager role that forecasted and tracked digital service revenues. Process managers also ensured that ERPs could manage varying service contract configurations. This was crucial for sales operations:

We once had a model in [the ERP that accounted for the service subscription term length]. So, for example, if [the customer] signs a 10-year contract for this service, he gets a lower price. If he signs up for two years, then it's a standard price that's higher. This was a complete overload for the sales force because customers had completely different terms for different contracts and customer then always got different prices for the same service. [...] We discarded this [model] quite quickly, also because the system did not allow us to present it in a great way. (N03) 


\subsubsection{Renewing routines}

Routines along the sales funnel were renewed to drive DSSA. Lead identification and follow-up routines were updated to find digital service leads in new equipment sales and extant maintenance contracts. To accelerate the growth of its digital service business, Jupiter added digital services to its lead referral program:

If along his field intervention, the [service technician] brings a lead for a small migration, he is compensated with one percent of the sales volume. If it's a service contract we're able to sign, it's three percent. That's not only for service technicians, but also our sales force, that is, product sales. (J06)

Area sales have a lead program with digital targets. They need to bring two leads per month. We have thirty salespeople out there who should bring in sixty leads per month. (J10)

Value-based selling gained traction with service digitalization. Typically, ordinary maintenance interventions and contracts were mandated by urgencies or law. Hence, their benefits required limited explanation. Digital services, by contrast, were often considered as discretionary spending. Salespeople had to prove the additional value digital services created:

Consider a reduction of delay minutes. We calculate [financial amount $\mathrm{x}$ ] per passenger delay minute. And we have offered a service to permanently monitor [train] doors in order to be able to do predictive maintenance. In other words, we maintain the doors in such a way that they never malfunction. Availability on [a specific route] has increased by $70 \%$, thanks to this. And if you now convert this into passenger delay minutes that have improved, it has a financial impact. (M05)

Innovative revenue models also required reinvigorated pricing routines. The firms relied predominantly on rigid pricing routines, using service operations costs and macroeconomic factors as their main input. To transition toward recurring (freemium/subscription) or usage-based (pay-per-X) revenue models, pricing routines had to become more flexible. Multiple iterations were needed to adjust prices to customer value creation:

We had a slightly more expensive pricing before, which has now been adjusted downward. But we have also had cheaper pricing right at the beginning, which was then corrected upward. It means we are now in the third pricing loop for [remote monitoring], in which we have already learned a few lessons. (N03)

\subsection{Meso-level enablers}

\subsubsection{Upgrading information technology systems}

Transparency of the installed base was essential to identify service sales leads. Customer relationship management (CRM) systems served to store and retrieve customer relationship data, including details about visits, contracts and the installed base.

Specifically, information about the number, location, type and age of the installed equipment was crucial. For physical services, this information was screened for opportunities to renew maintenance contracts or cross-sell other services, such as retrofits. For digital services, this information was necessary to identify equipment that could be connected to the internet and serviced digitally. The accuracy of this information was decisive for FLEs serving customers with heterogeneous installed bases:

We receive some leads for retrofits. But they are not differentiated as to whether they make sense or not, just: 'This equipment doesn't have any digital service - try to sell digital services there.' Whether this is a single-asset customer or a customer with one hundred assets, is not differentiated. Preparatory work has simply not been invested in a way that would make sense for me to use this as a basis for my work, especially regarding digital services. (N05)

CRM-enabled DSSA evolved in four stages. First, access barriers to CRM systems had to be lowered. Informants indicated that current CRM systems were insufficiently used due to poor graphic design and usability, incompatibility with mobile devices and lacking system interfaces or access rights. To address these deficiencies, most companies had recently launched or were about to launch new CRM systems.

Second, managers and FLEs had to accept the concept. Informants admitted not using their CRM, perceiving too few benefits compared to the effort of feeding data into the system. Managerial commitment was essential to drive CRM adoption:

I focused too much on the salespeople and not on their bosses. First, it's to convince branch managers and service managers of the benefits they can have with the [CRM]. And then, if you convince them, then they will make it work. But [what] if you just train the people [and] tell them, 'This helps you in your daily activities,' but their direct boss doesn't request them or even ask them about that? They have to be very, very process-oriented people to keep [on] doing it. So, this was how I failed. (N13)

Third, CRM data had to be exploited. Some FLEs fed the CRM with data, ignoring how the data would later be used or how to extract the data themselves:

We are putting everything, every order information into the CRM. But, actually, is the CRM supporting us or not? I don't know. (P15)

Fourth, CRM-based activity management was imperative. Informants deemed the planning, execution and monitoring of frontline activities based on up-to-date CRM data to be essential for selling digital services:

In terms of CRM-based sales, we're still in the Middle Ages at [Neptune]. For example, visit reports, we're at level zero. Now, applying this to digital services: I think, this approach - that salespeople are let loose on customers like in the Wild West - [...] is not the right approach. (N01)

ERP systems required upgrades to expedite new pricing mechanisms. Venus was unable to introduce features-ondemand for its digital services because the ERP did not allow a temporary limiting of feature access. Neptune was unable to apply usage-based pricing for a digital service because of the restrictions imposed by the ERP:

We need to count these calls in some form. How often does [a customer] send a request to our system to obtain data? We need to measure that. But we can't, simply because our ERP is not designed for that. (N08)

\subsubsection{Restructuring organizations}

Each firm approached structural ambidexterity differently. Jupiter's customer service unit harbored ambidextrous salespeople for physical and digital services. A recently formed digital unit added more specialized, digital-service-sales representatives. Venus formed a cross-functional digital service go-to-market team. This team accessed the resources of different organizational functions, notably after-sales and development, but had no profit and loss accountability. In addition to two goods-centric sales units, Mars introduced digital-service-sales roles within its customer service unit to approach customers. Organizational integration avoids overwhelming customers with competing sales forces:

Today, we have at least three sales units approaching the same customer. One sells vehicles, the other infrastructure, the third services for vehicles and infrastructure. Ideally, there would be one [Mars] sales organization selling solutions to the customer. But we haven't got that far yet. (M05) 
Conversely, Neptune re-integrated its digital unit after a few years of separation. The intention of the re-integration was to drive "customer-centricity" (N07) and synergies between the physical and digital service business:

We are now all part of one big organization called Operations. In Operations there are the big business lines new installations, modernization, and service. In each line you have sales and fulfillment. In the past, [subsidiaries] still had huge product management and developed some of the services themselves. This will be somewhat reduced, because - of course - as a company we live on standardization. In Service, [...] digitalization allows us to be a bit more flexible, because we have new services that are based purely on remote monitoring, like remote inspections, remote interactions, remote recoveries of units, in combination with physical visits. (N07)

\subsubsection{Aligning control systems}

An objective fact base is essential to manage performance. Measuring service profitability is a first step in this direction. Some companies had achieved this since the early 2000s to enhance "professionality in services" (J09). Conversely, "[b]ecause [Pluto] today... [as we say in China is] like a stateowned company," (P16) it must still take this step by following a strategic transformation plan to drive the competitiveness of its service business.

The monitoring of financial and non-financial metrics evolved alongside portfolios. Revenue and profitability measures were grouped in three baskets, namely, spare parts, maintenance and digital services. Sometimes, to track recurring revenues, maintenance was subdivided into field interventions and contracts. Because of the equal importance of the monitoring of non-financial metrics, connectivity rates of newly sold equipment were measured to ease the penetration of digital services. Companies also made significant efforts to improve measurement and to follow up customer satisfaction, often using the net promoter score (NPS).

Incentives were a crucial organizational enabler of DSSA. At the time of the research, physical goods and services generated considerably more revenue and profits than digital services. Most incentive systems, however, solely focused on backwardlooking financial metrics without accounting for the growth potential of digital services:

\section{Revenue is the main concern. Digital services are not generating much revenue at the moment, which is why many salespeople are simply ignoring them. Everyone is rushing into the big retrofit projects, the big spare parts packages, the big connectivity projects. But selling a [cloud service] tenant for CHF 2,000 a year is at least as much work as the retrofit. But then you get 2,000 instead of 100,000 . That's a bit of a conflict. That's why revenue targets partly stand in the way of pushing these new technologies really hard on the market. For this you would almost have to leave revenue targets out and just say: 'We now have this solution. It doesn't make any money today, but it's the future. Now go out with this, so that we can plant the seed somewhere, so that at some point it will grow into a plant, at some point into a tree. But don't look so much at revenue but go and sell that many [cloud service] tenants.' (J04)}

The alignment of managerial and FLE incentives fostered DSSA behavior. Managerial compensation in Mars' service sales organization was linked to a broader set of metrics. To balance sales-related and service-related behavior, managerial metrics included order intake, sales expenses, profitability and NPS. FLE incentives were aligned in two ways. First, by streamlining incentives across physical goods, services and digital service sales roles:

The [head of service sales] and [digital service sales representatives] now have exactly the same objectives as the salespeople selling trains or infrastructure. That helped a lot. Now it's not anymore about where people book the sale, but just: 'Let's sell that together.' (M05)
Second, by adding specific digital service sales incentives. At Jupiter, the relative weighting of such incentives ranged from "a small percentage share" (J06) for area sales managers, through "a small factor" (J05) for service salespeople, to "50/50" (J10) for digital service sales representatives. Neptune piloted similar incentives in its sales force. For equipment salespeople, a certain share of elevator and escalator sales agreements had to include digital services. Service salespeople's compensation plans were revamped - at the time of the research - and included incentives to sell maintenance contracts and digital services.

\section{Discussion}

Many industrial firms struggle - simultaneously - to capture revenues from proven physical services and to grow their digital service business. Despite its importance for both goals, researchers have not studied SSA in terms of a digital servitization perspective. Our study addressed this gap by exploring DSSA and its organizational enablers in five industrial firms, and produced three key research takeaways:

- DSSA encapsulates the ability to achieve service-related and sales-related outcomes in the physical and digital service spheres.

- DSSA is a multilevel phenomenon: organization-level DSSA is a dynamic capability that rests on individual-level DSSA behavior.

- Eight organizational enablers, running at the macro, micro and meso levels, facilitate DSSA.

\subsection{Theoretical implications}

\subsubsection{Digital service-sales ambidexterity}

Prior literature has evaluated digital servitization and SSA separately. This study, by proposing the DSSA concept, is the first to combine both perspectives. Our findings suggest that many FLEs fail to sell digital services (Paiola and Gebauer, 2020) because service digitalization fuels SSA-related role ambiguity (Yu et al., 2015). Subject to a top-down, inorganic role expansion (Hughes and Ogilvie, 2020; Ruyter et al., 2020), FLEs in digitally servitizing firms now have to develop KSAs in a $2 \times 2$ matrix of activities (service; sales) and services (physical; digital), even though FLE compensation is not always commensurate with the incremental resource and KSA demands imposed by digital services. With appropriate organizational mechanisms in place, DSSA presents a way out of the "digitalization paradox" (Gebauer et al., 2020). Without organizational adjustments, service digitalization risks making the "dark side of ambidexterity" (Gabler et al., 2017) even darker.

\subsubsection{The multilevel nature of digital service-sales ambidexterity} Scholars have called for multilevel research to better understand SSA and its enablers (Hughes and Ogilvie, 2020; Rapp et al., 2017). We respond to these calls by conceptualizing DSSA at the organizational and individual level. Organizationlevel DSSA is a dynamic capability because it reflects a firm's ability to reconfigure and modify service and sales resources (Helfat et al., 2007), to achieve a superior level of performance. More specifically, ambidextrous firms can reconfigure human resources (e.g. FLEs), intangible resources (e.g. IT systems) 
and capabilities (e.g. service selling) to exploit and explore, thus supporting the firm's long-term survival (Helfat et al., 2007).

Furthermore, we build on the SSA (Rapp et al., 2017) and the microfoundations literature (Felin et al., 2012) to show that the organization-level DSSA capability rests on individual-level DSSA. Our results indicate that organizations can only become ambidextrous if individuals leverage the necessary KSAs (Barney and Felin, 2013). Both managers and FLEs must consistently display DSSA behavior - by encouraging and engaging in service and sales activities for physical and digital services - to attain the DSSA capability (Abell et al., 2008).

5.1.3 Eight organizational enablers of digital service-sales ambidexterity Research on organizational drivers of SSA - although necessary is minimal (Mullins et al., 2020; Panagopoulos et al., 2020; Shiue et al., 2021). We extend prior knowledge by operationalizing eight organizational enablers of DSSA (Table 3).

In doing so, we contribute to the servitization and SSA literature. Servitization research has made little attempt to decipher organizational mechanisms alleviating tensions in the service-sales interface (Raddats et al., 2019). The eight organizational enablers represent a first foray in this domain.

Moreover, this research contributes to the SSA literature by revealing a certain equifinality (Gresov and Drazin, 1997) of structural and contextual approaches to ambidexterity (Gibson and Birkinshaw, 2004). Structural approaches overcome service/sales-related role ambiguity by creating separate organizational units or roles (Gabler et al., 2017; Rapp et al., 2017). We expand this understanding by illustrating that firms create separate structures, such as cross-functional teams (Raisch et al., 2009) or independent units (O'Reilly and Tushman, 2013) but also that they may dissolve them once the digital services have gained traction. Moreover, we find that industrial firms use separate roles like those of digital service salespeople to prove structural ambidexterity. This observation resonates with Hochstein et al. (2021), who highlight the effectiveness of structural approaches - based on specialized roles - to develop organization-level SSA.

Nonetheless, the results suggest that contextual mechanisms do matter. Because "traditional" service and sales FLEs typically outnumber digital service salespeople, more mechanisms are needed to instill DSSA behavior in the frontline. Insights into the organizational enablers of contextual ambidexterity (Gibson and Birkinshaw, 2004) are vital because, eventually, FLEs - on their own - need to tackle the challenges posed by the pursuit of conflicting goals (Jasmand et al., 2012; Yu et al., 2015). By unpacking organizational mechanisms such as resource reallocation, KSA enhancement or control system alignment, this research contributes to the bourgeoning SSA enablement literature (Hughes and Ogilvie, 2020; Mullins et al., 2020; Panagopoulos et al., 2020) and advises managers how to cultivate DSSA within existing structures.

\subsection{Managerial implications}

5.2.1 Set separate strategic objectives but pivot if necessary

It is unlikely that many digital services will soon reach the revenue levels of physical services. Still, to protect current

Table 3 Eight operationalized organizational enablers of DSSA

\begin{tabular}{llll}
\hline \multicolumn{2}{l}{ Organizational enablers } & \\
Level & $\#$ & Enabler & Abstract concepts from prior SSA literature. . \\
\hline Macro & 1 & Refining objectives & $\begin{array}{l}\text { SSA enables "firms to align sales- and service- } \\
\text { related strategic foci" (Rapp et al., 2017, p. 62) }\end{array}$
\end{tabular}

2 Reallocating resources

Micro 3 Enhancing KSAs

4 Transforming frontline roles

$5 \quad$ Renewing routines

Meso $\quad 6 \quad \begin{aligned} & \text { Upgrading } \\ & \text { IT systems }\end{aligned}$

IT systems

$7 \quad$ Restructuring organizations

$8 \quad$ Aligning control systems
"SSA behaviors impose significant resource limitations" (Mullins et al., 2020, p. 38)

"[F]irms should consider establishing ambidexterity in skill-enhancing practices" (Panagopoulos et al., 2020, p. 97)

Roles are renewed (Yu et al., 2013) by adding responsibilities to frontline roles (Rapp et al., 2017) and recruiting candidates who display ambidextrous behavior (Hughes and Ogilvie, 2020)

SSA requires abandoning outdated routines (Yu et al., 2013)

Tools to enhance selling efficiency (Hughes and Ogilvie, 2020; Ruyter et al., 2020) and customer relationships (Gabler et al., 2017) must be deployed, notably CRM systems (Giovannetti et al., 2020) Service and sales functions must be separated to achieve structural ambidexterity (Jasmand et al., 2012; Ruyter et al., 2020).

Control systems should balance conflicting objectives (DeCarlo and Lam, 2016; Panagopoulos et al., 2020; Yu et al., 2013) and include forwardlooking metrics (Hughes and Ogilvie, 2020)

\section{... are operationalized in this study}

The formulation of strategic objectives such as digital service revenue, maintenance contract closures, spare parts revenue or installed base connectivity

The deployment of hybrid sales structures leveraging tele-sales to overcome resource limitations The use of training, workshops, brochures and showrooms to improve DSSA-related KSAs

The addition of responsibilities to frontline roles to sell digital services, and the creation of new (digital) service sales roles

The renewal of lead identification, follow-up, selling and pricing routines

The updating, deployment and leveraging of CRMs to manage frontline activities and the adjustment of ERPs to new pricing mechanisms

The establishment of separate digital services units in some firms and the reintegration of digital units or the building of cross-functional teams in other firms The linking of managerial compensation to profit and NPS, the inclusion of incentives for digital service sales in frontline plans and the use of roledependent, relative weighting 
margins and preserve future growth options, executives must set specific objectives in both domains. Non-financial metrics, such as the share of new equipment sold with active connectivity, can pave the way for future digital service growth without imposing unrealistic revenue targets. Importantly, executives should remain open to adjusting objectives based on market feedback. Our study is sobering because it describes how companies degrade digital services from a topline growth engine to an add-on to the core business. Executives should consider this caveat when defining service growth targets.

\subsubsection{Get all frontline employees "up to digital speed" but concentrate expertise in specialist roles}

It is important that the entire service and sales frontline develop a basic understanding of the technology and customer value behind digital services. Although "traditional" service and sales FLEs still occupy most customer touchpoints, many lack the KSAs required to sell digital services. This is unfortunate because ambidextrous FLEs are indispensable to identify service sales leads and to realize the full potential of crossselling and up-selling opportunities. Hence, leaders should mandate role-specific digital service training for all FLEs. However, it is neither economical nor realistic to transform the entire frontline into digital services sellers. Therefore, leaders should first pick the "low hanging fruit" by selecting the most digital-savvy FLEs before developing them into digital champions or service salespeople.

Leaders ought to take more incisive decisions if this approach fails[3]. Some FLEs will be unable or unwilling to develop KSAs for selling digital services. If the number of digitalcompetent employees is insufficient and natural employee fluctuation is too slow, managers should - as a last resort consider ending those FLEs who resist change. The later hiring procedure must include selection mechanisms (e.g. digitally focused online tests or in-depth interviews) to ensure that only suitable candidates permeate the application process.

\subsubsection{Upgrade information technology systems before updating individual metrics}

FLE enablement starts with high-performing CRM and ERP systems. CRM systems that promote the transparency of the installed base and customer relationships are essential to identify up-selling opportunities, tailor service sales campaigns and guide frontline activities. Similarly, ERP systems should be upgraded to remove barriers preventing the selling of customerspecific service packages and the implementation of new pricing mechanisms. Only when a comprehensive fact base about service and sales potential and performance exists can managers adapt metrics that steer individuals in the intended direction.

\subsection{Limitations and research directions}

This study suffers from limitations of methodology, sample and scope. As we used qualitative methods, the usual caveats about generalizability apply. Moreover, our data come from interviews. A longitudinal study, collecting objective service and sales performance data, would be useful to further explore the cross-level dynamics of DSSA and to answer, among others, the following questions: Is DSSA necessarily inorganic and top-down (Hughes and Ogilvie, 2020)? Do firms with higher levels of DSSA attract and nurture individuals who display higher degrees of DSSA behavior? Is DSSA development primarily a bottom-up phenomenon (Ruyter et al., 2020) in which ambidextrous individuals engage in activities that lead to organization-level DSSA?

Moreover, we selected cases based on convenience rather than on pure theoretical sampling (Glaser and Strauss, 1967). There are industries, firms or individuals displaying even higher degrees of DSSA that are worth studying. Specifically, the ambidextrous "customer success manager" role has permeated software firms to surface - through the present emergence of recurring revenue-based services - in more traditional industries (Hochstein et al., 2021). It would be interesting to examine how industrial firms implement this role and which organizational enablers they use. Furthermore, our principal scope was the service and sales field force in digitally servitizing firms. This limitation offers two, potentially rewarding, research directions. First, as we only scratched the surface of hybrid sales organizations, more research is needed to investigate how the inside sales force (Sleep et al., 2020) can resolve goal conflicts inherent in DSSA. Second, as highlighted at the outset, research on the digital transformation of selling is gaining momentum (Mattila et al., 2021). Because digitalization affects both sales and service operations (Singh et al., 2019), future research should explore how digital services generate data that are simultaneously exploitable for sales force automation and service fulfillment.

Finally, questions remain about the outlined organizational enablers. When, regarding digital services, should sales executives pivot from non-financial to financial targets? Which digital services warrant specialized sales roles? Which screening and training procedures are effective in finding and developing ambidextrous FLEs? What are "best-practice" control systems for digital services? How do compensation plans relate to the used revenue model (Classen and Friedli, 2021)? We hope that our DSSA theory will encourage more research on this academically and managerially relevant topic.

\section{Notes}

1. We use the term physical services for services fulfilled exclusively by physical means (i.e. "non-digital services"; Raddats et al., 2019), such as product installations, retrofits and repair. We use the term digital services for services in which fulfillment is partially or entirely digital and enabled by data exploitation, like in remote and predictive maintenance services (Lerch and Gotsch, 2015; Opresnik and Taisch, 2015).

2. Supporting documents, obtained from Venus' Head of Service, bolster the internal reliability (Jick, 1979) of our interview data and reduce concerns about the relatively small number of informants (3).

3. We thank an anonymous reviewer for this insight.

\section{References}

Abell, P., Felin, T. and Foss, N. (2008), "Building microfoundations for the routines, capabilities, and performance 
links", Managerial and Decision Economics, Vol. 29 No. 6, pp. 489-502.

Agnihotri, R., Gabler, C.B., Itani, O.S., Jaramillo, F. and Krush, M.T. (2017), "Salesperson ambidexterity and customer satisfaction: examining the role of customer demandingness, adaptive selling, and role conflict", fournal of Personal Selling \& Sales Management, Vol. 37 No. 1, pp. 27-41.

Barney, J. and Felin, T. (2013), "What are microfoundations?", Academy of Management Perspectives, Vol. 27 No. 2, pp. 138-155.

Böhm, E., Eggert, A. and Thiesbrummel, C. (2017), "Service transition: a viable option for manufacturing companies with deteriorating financial performance?", Industrial Marketing Management, Vol. 60, pp. 101-111.

Burton, J., Story, V.M., Raddats, C. and Zolkiewski, J. (2017), "Overcoming the challenges that hinder new service development by manufacturers with diverse services strategies", International fournal of Production Economics, Vol. 192, pp. 29-39.

Burton, J., Story, V., Zolkiewski, J., Raddats, C., Baines, T.S. and Medway, D. (2016), "Identifying tensions in the servitized value chain", Research-Technology Management, Vol. 59 No. 5, pp. 38-47.

Churchill, G.A., Ford, N.M., Hartley, S.W. and Walker, O.C. (1985), "The determinants of salesperson performance: a meta-analysis", fournal of Marketing Research, Vol. 22 No. 2, pp. 103-118.

Classen, M. and Friedli, T. (2021), "It's not like we can charge for everything': revenue models to capture value from smart services in Pacific Asia”, Asia Pacific Business Review, Vol. 27 No. 3, pp. 405-430.

Collis, D.J. (1994), "Research note: how valuable are organizational capabilities?", Strategic Management fournal, Vol. 15 No. 1, pp. 143-152.

Corbin, J.M. and Strauss, A.L. (2008), Basics of Qualitative Research: Techniques and Procedures for Developing Grounded Theory, 3rd ed., Sage Publ, Los Angeles, Calif.

Coreynen, W., Matthyssens, P. and van Bockhaven, W. (2017), "Boosting servitization through digitization: pathways and dynamic resource configurations for manufacturers", Industrial Marketing Management, Vol. 60, pp. $42-53$.

Coreynen, W., Matthyssens, P., Vanderstraeten, J. and van Witteloostuijn, A. (2020), "Unravelling the internal and external drivers of digital servitization: a dynamic capabilities and contingency perspective on firm strategy", Industrial Marketing Management, Vol. 89, pp. 265-277.

DeCarlo, T.E. and Lam, S.K. (2016), "Identifying effective hunters and farmers in the salesforce: a dispositionalsituational framework", fournal of the Academy of Marketing Science, Vol. 44 No. 4, pp. 415-439.

Eggert, A., Hogreve, J., Ulaga, W. and Muenkhoff, E. (2014), "Revenue and profit implications of industrial service strategies", Fournal of Service Research, Vol. 17 No. 1, pp. 23-39.

Eisenhardt, K.M. (1989), "Building theories from case study research", The Academy of Management Review, Vol. 14 No. 4 , p. 532.
Eloranta, V. and Turunen, T. (2015), "Seeking competitive advantage with service infusion: a systematic literature review", fournal of Service Management, Vol. 26 No. 3, pp. 394-425.

Fang, E., Palmatier, R.W. and Steenkamp, J.-B.E. (2008), "Effect of service transition strategies on firm value", fournal of Marketing, Vol. 72 No. 5, pp. 1-14.

Felin, T., Foss, N.J., Heimeriks, K.H. and Madsen, T.L. (2012), "Microfoundations of routines and capabilities: individuals, processes, and structure", Fournal of Management Studies, Vol. 49 No. 8, pp. 1351-1374.

Gabler, C.B., Ogilvie, J.L., Rapp, A. and Bachrach, D.G. (2017), "Is there a dark side of ambidexterity? Implications of dueling sales and service orientations", fournal of Service Research, Vol. 20 No. 4, pp. 379-392.

Gebauer, H., Fleisch, E. and Friedli, T. (2005), "Overcoming the service paradox in manufacturing companies", European Management fournal, Vol. 23 No. 1, pp. 14-26.

Gebauer, H., Fleisch, E., Lamprecht, C. and Wortmann, F. (2020), "Growth paths for overcoming the digitalization paradox”, Business Horizons, Vol. 63 No. 3, pp. 313-323.

Gebauer, H. and Friedli, T. (2005), "Behavioral implications of the transition process from products to services", fournal of Business E Industrial Marketing, Vol. 20 No. 2, pp. 70-78.

Gibson, C.B. and Birkinshaw, J. (2004), "The antecedents, consequences, and mediating role of organizational ambidexterity", Academy of Management Fournal, Vol. 47 No. 2, pp. 209-226.

Gioia, D.A., Corley, K.G. and Hamilton, A.L. (2013), "Seeking qualitative rigor in inductive research", Organizational Research Methods, Vol. 16 No. 1, pp. 15-31.

Giovannetti, M., Cardinali, S. and Sharma, P. (2020), "Sales technology and salespeople's ambidexterity: an ecosystem approach", fournal of Business $\mathcal{E}$ Industrial Marketing, Vol. 36 No. 4.

Glaser, B.G. and Strauss, A.L. (1967), The Discovery of Grounded Theory: Strategies for Qualitative Research, 1st ed., New Brunswick, Aldine.

Gresov, C. and Drazin, R. (1997), "Equifinality: functional equivalence in organization design", The Academy of Management Review, Vol. 22 No. 2, pp. 403-428.

Guenzi, P. and Habel, J. (2020), "Mastering the digital transformation of sales", California Management Review, Vol. 62 No. 4, pp. 57-85.

Hasselblatt, M., Huikkola, T., Kohtamäki, M. and Nickell, D. (2018), “Modeling manufacturer's capabilities for the internet of things", fournal of Business E Industrial Marketing, Vol. 33 No. 6, pp. 822-836.

Helfat, C.E., Finkelstein, S., Mitchell, W., Peteraf, M.A., Singh, H. and Winter, S.G. (2007), Dynamic Capabilities: Understanding Strategic Change in Organizations, Blackwell Publ, Malden, MA.

Hochstein, B., Chaker, N.N., Rangarajan, D., Nagel, D. and Hartmann, N.N. (2021), "Proactive value Co-Creation via structural ambidexterity: customer success management and the modularization of frontline roles", fournal of Service Research, Vol. 24 No. 4.

Hughes, D.E. and Ogilvie, J.L. (2020), "When sales becomes service: the evolution of the professional selling role and an 
organic model of frontline ambidexterity", Fournal of Service Research, Vol. 23 No. 1, pp. 22-32.

Huikkola, T. and Kohtamäki, M. (2017), "Solution providers' strategic capabilities", Fournal of Business \& Industrial Marketing, Vol. 32 No. 5, pp. 752-770.

Jasmand, C., Blazevic, V. and Ruyter, K. D. (2012), "Generating sales while providing service: a study of customer service representatives' ambidextrous behavior", Fournal of Marketing, Vol. 76 No. 1, pp. 20-37.

Jick, T.D. (1979), "Mixing qualitative and quantitative methods: triangulation in action", Administrative Science Quarterly, Vol. 24 No. 4, p. 602.

Kindström, D. and Kowalkowski, C. (2014), "Service innovation in product-centric firms: a multidimensional business model perspective”, Fournal of Business $\mathcal{E}$ Industrial Marketing, Vol. 29 No. 2, pp. 96-111.

Kindström, D., Kowalkowski, C. and Alejandro, T.B. (2015), "Adding services to product-based portfolios", fournal of Service Management, Vol. 26 No. 3, pp. 372-393.

Klein, M., Biehl, S. and Friedli, T. (2018), "Barriers to smart services for manufacturing companies - an exploratory study in the Capital goods industry", fournal of Business $\mathcal{E}$ Industrial Marketing, Vol. 33 No. 6, pp. 846-856.

Klein, K.J. and Kozlowski, S.W.J. (2000), "From micro to meso: critical steps in conceptualizing and conducting multilevel research", Organizational Research Methods, Vol. 3 No. 3, pp. 211-236.

Kohtamäki, M., Parida, V., Oghazi, P., Gebauer, H. and Baines, T. (2019), "Digital servitization business models in ecosystems: a theory of the firm", fournal of Business Research, Vol. 104, pp. 380-392.

Kozlenkova, I.V., Samaha, S.A. and Palmatier, R.W. (2014), "Resource-based theory in marketing", fournal of the Academy of Marketing Science, Vol. 42 No. 1, pp. 1-21.

Lam, S.K., DeCarlo, T.E. and Sharma, A. (2019), "Salesperson ambidexterity in customer engagement: do customer base characteristics matter?", fournal of the Academy of Marketing Science, Vol. 47 No. 4, pp. 659-680.

Lerch, C. and Gotsch, M. (2015), "Digitalized ProductService systems in manufacturing firms: a case study analysis", Research-Technology Management, Vol. 58 No. 5, pp. 45-52.

Lütjen, H., Tietze, F. and Schultz, C. (2017), "Service transitions of product-centric firms: an explorative study of service transition stages and barriers in Germany's energy market", International fournal of Production Economics, Vol. 192, pp. 106-119.

March, J.G. (1991), "Exploration and exploitation in organizational learning”, Organization Science, Vol. 2 No. 1, pp. 71-87.

Mattila, M., Yrjölä, M. and Hautamäki, P. (2021), "Digital transformation of business-to-business sales: what needs to be unlearned?", Fournal of Personal Selling \& Sales Management, Vol. 41 No. 2, pp. 113-129.

Miles, M.B., Huberman, A.M. and Saldaña, J. (2014), Qualitative Data Analysis: A Methods Sourcebook, 3rd ed, Sage, Los Angeles, CA.

Morgan, N.A. (2012), "Marketing and business performance", Fournal of the Academy of Marketing Science, Vol. 40 No. 1, pp. 102-119.
Mullins, R., Agnihotri, R. and Hall, Z. (2020), "The ambidextrous sales force: aligning salesperson polychronicity and selling contexts for Sales-Service behaviors and customer value", fournal of Service Research, Vol. 23 No. 1, pp. 33-52.

Nag, R. and Gioia, D.A. (2012), "From common to uncommon knowledge: foundations of Firm-Specific use of knowledge as a resource", Academy of Management fournal, Vol. 55 No. 2, pp. 421-457.

Nezami, M., Worm, S. and Palmatier, R.W. (2018), "Disentangling the effect of services on B2B firm value: trade-offs of sales, profits, and earnings volatility", International fournal of Research in Marketing, Vol. 35 No. 2, pp. 205-223.

Ogilvie, J., Rapp, A., Bachrach, D.G., Mullins, R. and Harvey, J. (2017), "Do sales and service compete? The impact of multiple psychological climates on frontline employee performance", in Fournal of Personal Selling \& Sales Management, Vol. 37 No. 1, pp. 11-26, doi: 10.1080/ 08853134.2016.1276398.

Oliva, R. and Kallenberg, R. (2003), "Managing the transition from products to services”, International fournal of Service Industry Management, Vol. 14 No. 2, pp. 160-172.

Opresnik, D. and Taisch, M. (2015), "The value of big data in servitization", International fournal of Production Economics, Vol. 165, pp. 174-184.

O'Reilly, C.A. and Tushman, M.L. (2008), "Ambidexterity as a dynamic capability: resolving the innovator's dilemma", Research in Organizational Behavior, Vol. 28, pp. 185-206.

O'Reilly, C.A. and Tushman, M.L. (2013), "Organizational ambidexterity: past, present, and future", Academy of Management Perspectives, Vol. 27 No. 4, pp. 324-338.

Paiola, M. and Gebauer, H. (2020), "Internet of things technologies, digital servitization and business model innovation in BtoB manufacturing firms", Industrial Marketing Management.

Paiola, M., Saccani, N., Perona, M. and Gebauer, H. (2013), "Moving from products to solutions: strategic approaches for developing capabilities", European Management fournal, Vol. 31 No. 4, pp. 390-409.

Panagopoulos, N.G., Rapp, A. and Pimentel, M.A. (2020), "Firm actions to develop an ambidextrous sales force", Fournal of Service Research, Vol. 23 No. 1, pp. 87-104.

Patterson, P., Yu, T. and Kimpakorn, N. (2014), "Killing two birds with one stone: cross-selling during service delivery", in Fournal of Business Research, Vol. 67 No. 9, pp. 1944-1952, doi: 10.1016/j.jbusres.2013.11.013.

Patton, M.Q. (2002), Qualitative Research E Evaluation Methods, 3rd ed., Sage, Thousand Oaks, CA.

Rabetino, R., Kohtamäki, M. and Gebauer, H. (2017), "Strategy map of servitization", International fournal of Production Economics, Vol. 192, pp. 144-156.

Raddats, C. Kowalkowski, C. Benedettini, O. Burton, J. and Gebauer, H. (2019), "Servitization: a contemporary thematic review of four major research streams", Industrial Marketing Management.

Raisch, S., Birkinshaw, J., Probst, G. and Tushman, M.L. (2009), "Organizational ambidexterity: balancing exploitation and exploration for sustained performance", Organization Science, Vol. 20 No. 4, pp. 685-695. 
Rapp, A., Bachrach, D.G., Flaherty, K.E., Hughes, D.E., Sharma, A. and Voorhees, C.M. (2017), "The role of the Sales-Service interface and ambidexterity in the evolving organization", Fournal of Service Research, Vol. 20 No. 1, pp. 59-75.

Reinartz, W.J. and Ulaga, W. (2008), "How to sell services more profitably", Harvard Business Review, Vol. 86 No. 5, pp. $90-96+129$.

Ritter, T. and Pedersen, C.L. (2019), "Digitization capability and the digitalization of business models in business-tobusiness firms: past, present, and future", Industrial Marketing Management.

Ruyter, K. D., Keeling, D.I. and Yu, T. (2020), “Service-Sales ambidexterity: evidence, practice, and opportunities for future research", fournal of Service Research, Vol. 23 No. 1, pp. 13-21.

Salvato, C. and Rerup, C. (2011), "Beyond collective entities: multilevel research on organizational routines and capabilities", fournal of Management, Vol. 37 No. 2, pp. 468-490.

Shiue, W., Tuncdogan, A., Wang, F. and Bredican, J. (2021), "Strategic enablers of service-sales ambidexterity: a preliminary framework and research agenda", Industrial Marketing Management, Vol. 92, pp. 78-86.

Singh, J., Flaherty, K., Sohi, R.S., Deeter-Schmelz, D., Habel, J., Le Meunier-FitzHugh, K., Malshe, A., Mullins, R. and Onyemah, V. (2019), "Sales profession and professionals in the age of digitization and artificial intelligence technologies: concepts, priorities, and questions", Fournal of Personal Selling \& Sales Management, Vol. 39 No. 1, pp. 2-22.

Sleep, S., Dixon, A.L., DeCarlo, T.E. and Lam, S.K. (2020), "The business-to-business inside sales force: roles, configurations and research agenda", European fournal of Marketing, Vol. 54 No. 5, pp. 1025-1060.

Sok, K.M., Sok, P. and Luca, L.M. D. (2016), "The effect of 'can do' and 'reason to' motivations on service-sales ambidexterity", Industrial Marketing Management, Vol. 55, pp. 144-155.

Strauss, A.L. (1987), Qualitative Analysis for Social Scientists, Cambridge Univ. Press, Cambridge.

Suppatvech, C. Godsell, J. and Day, S. (2019), "The roles of internet of things technology in enabling servitized business models: a systematic literature review", Industrial Marketing Management.

Teece, D.J. (2007), "Explicating dynamic capabilities: the nature and microfoundations of (sustainable) enterprise performance", Strategic Management fournal, Vol. 28 No. 13, pp. 1319-1350.

Teece, D.J., Pisano, G. and Shuen, A. (1997), "Dynamic capabilities and strategic management", Strategic Management fournal, Vol. 18 No. 7, pp. 509-533.
Töytäri, P., Turunen, T., Klein, M., Eloranta, V., Biehl, S. and Rajala, R. (2018), "Aligning the mindset and capabilities within a business network for successful adoption of smart services", Fournal of Product Innovation Management, Vol. 35 No. 5, pp. 763-779.

Turunen, T. and Neely, A. (2012), “Organising servitization: an in-depth case study”, Report, Cambridge Service Alliance.

Ulaga, W. and Loveland, J.M. (2014), "Transitioning from product to service-led growth in manufacturing firms: emergent challenges in selecting and managing the industrial sales force", Industrial Marketing Management, Vol. 43 No. 1, pp. 113-125.

Ulaga, W. and Reinartz, W.J. (2011), "Hybrid offerings: how manufacturing firms combine goods and services successfully", Fournal of Marketing, Vol. 75 No. 6, pp. 5-23.

van Maanen, J. (1979), "The fact of fiction in organizational ethnography", Administrative Science Quarterly, Vol. 24 No. 4, p. 539.

Vandermerwe, S. and Rada, J. (1988), "Servitization of business: adding value by adding services", European Management fournal, Vol. 6 No. 4, pp. 314-324.

Vendrell-Herrero, F., Bustinza, O.F., Parry, G. and Georgantzis, N. (2017), "Servitization, digitization and supply chain interdependency", Industrial Marketing Management, Vol. 60, pp. 69-81.

Winter, S.G. (2003), "Understanding dynamic capabilities", Strategic Management fournal, Vol. 24 No. 10, pp. 991-995.

Wise, R. and Baumgartner, P. (1999), "Go downstream - The new profit imperative in manufacturing", Harvard Business Review, Vol. 77 No. 5.

Worm, S., Bharadwaj, S.G., Ulaga, W. and Reinartz, W.J. (2017), "When and why do customer solutions pay off in business markets?", Fournal of the Academy of Marketing Science, Vol. 45 No. 4, pp. 490-512.

Yin, R.K. (2018), Case Study Research and Applications: Design and Methods, 6th ed., Sage, Los Angeles, London, New Delhi, Singapore, Washington, DC, Melbourne.

Yu, T., Patterson, P. and Ruyter, K.D. (2015), "Converting service encounters into cross-selling opportunities", European fournal of Marketing, Vol. 49 Nos 3/4, pp. 491-511.

Yu, T., Patterson, P.G. and Ruyter, K.D. (2013), “Achieving Service-Sales ambidexterity", fournal of Service Research, Vol. 16 No. 1, pp. 52-66.

Yu, T., Ruyter, K.d., Patterson, P. and Chen, C.-F. (2018), "The formation of a cross-selling initiative climate and its interplay with service climate", in EfM, Vol. 52 Nos 7/8, pp. 1457-1484, doi: 10.1108/EJM-08-2016-0487.

\section{Corresponding author}

Moritz Classen can be contacted at: moritz.classen@gmail. com 